\title{
The Impact of Regionalization on Eurasian Integration: Economic and Political Factors
}

\section{Khodor Shatila*, Marina Alozian}

Sagesse University, Lebanon, Beirut; * shatilakhodor@gmail.com

\begin{abstract} regional integration, collective security

\section{Влияние регионализации на евразийскую интеграцию: экономические и политические факторы}

This article discusses the legal aspects of regional integration processes in Eurasia. It argues that these processes are driven by both political and economic factors, which in particular include the desire on the international stage of a number of post-Soviet nations for regional peace and security as well as to create a greater and more effective economic system. It is often claimed that in the sense of two different yet strongly linked international organizations - with the same similar composition - the Collective Security Treaty Organisation (CSTO) and the EurAsEC, officially turning into the Eurasian Economic Union, unitedited Eurasia is hierarchical. The article then provides the history to CSTO and EurAsEC and discusses how they are to be combined. It also discusses the structural structure of these relationships and describes their goals, values, and main collaboration zones. Finally, the paper contains closing remarks aimed at highlighting problems and assessing opportunities for incorporation processes in Eurasia.

Keywords: Commonwealth of Independent States (CIS), Collective Security Treaty Organisation (CSTO), Eurasian Economic Community (EurAsEC), Eurasian Economic Union (EEU), Russia, Kazakhstan, Eurasia,

For citing: Khodor Sh., Alozian M. The Impact of Regionalization on Eurasian Integration: Economic and Political Factors // Eurasian integration: economics, law, politics. 2020. No. 3. Pp. 39-51.

\section{Ходор Ш.*, Алозян М.}

Sagesse University, Ливан, Бейрут; * shatilakhodor@gmail.com

РЕФЕРАТ

В статье рассматриваются правовые аспекты региональных интеграционных процессов в Евразии. Утверждается, что эти процессы обусловлены как политическими, так и экономическими факторами, которые, в частности, включают стремление ряда постсоветских стран на международной арене к региональному миру и безопасности, а также к созданию более масштабной и эффективной экономической системы. Часто утверждают, что относительно двух разных, но тесно связанных между собой международных организаций со схожим составом - Организации Договора о коллективной безопасности (ОДКБ) и ЕврАзЭС, официально формирующих Евразийский экономический союз, единая Евразия является иерархической. В статье рассматривается история ОДКБ и ЕврАзЭС и возможность их объединения. Также обсуждается организационная структура данных отношений и описываются их цели, ценности и основные зоны сотрудничества. В статье содержатся заключительные замечания, направленные на выявление проблем и оценку возможностей для процессов объединения в Евразии.

Ключевые слова: Содружество Независимых Государств (СНГ), Организация Договора о коллективной безопасности (ОДКБ), Евразийское экономическое сообщество (ЕврАзЭС), Евразийский экономический союз (ЕАЭС), Россия, Казахстан, Евразия, региональная интеграция, коллективная безопасность Для цитирования: Ходор Ш., Алозян М. Влияние регионализации на евразийскую интеграцию: экономические и политические факторы // Евразийская интеграция: экономика, право, политика. 2020. № 3. С. 39-51. 


\section{Introduction}

The regionalisation development is one of the most spectacular phenomena in modern global relations. Its main aim is to safeguard the political and economic interests of the Member States and to reflect globalization as well as to provide its response, the push towards regionalization, i. e. the process of forming regional integration groups, concurrent all over the world. Another main feature of such groups is that they are formed within certain areas, i. e. cohesive areas of the world, and have a certain degree of unity in international relations, which is a part of the international system. The groupings (as well as regions) are built and deconstructed through interactions between players of the international system. In addition, their creation reflects the ongoing transformation of the international system.

Currently Eurasia, which can include a substantial number of former Republics of the Union of Soviet Socialist Republics (USSR), is one of the major reconstructive areas. The current situation in that area is characterized fully in accordance with contemporary trends in global relations by the development of the regional integration processes. This paper intends to provide a summary of how these systems are created, to demonstrate their issues and their perspectives.

\section{Background of Integration Processes in Eurasia (Commonwealth of Independent States)}

Some of the most important global developments of the twentieth century - the fall of the USSR has indicated a rise in regionalization processes in recent decades. Notwithstanding judicial separation the successor countries of the Soviet Union share several common problems, as there have been numerous political and unprecedented challenges in the collapse of the Socialist System in Modern history. As a consequence, solutions were required to build new architectures in post-Soviet peace and security, and to synchronize the transition to a market economy and the Minsk Agreement, concluded on 8 December 1991 by Belarus, Russia and Ukraine, also declared the Commonwealth of Independent States (CIS) creation, which also involves Armenia, Azerbaijan, Kazakhstan, Moldova, Tajikistan, Turkmenistan, Uzbekistan, and on 21 December 1991. It was concluded.

However, from the very beginning, CIS functioning has been characterized by a fundamental disagreement of its members with respect to their organizations which can be confirmed by reviewing, in the following two major CIS objectives, the wording of the Minsk Agreement.

First, CIS members agreed to "support and maintain united-commanded a common military-strategic space, including unified controls on nuclear weapons" (which was obviously Russia's will), but there was a special agreement on the process of creating this space (a condition that reflected in particular the interests of the Ukraine).

Second, CIS members committed themselves to this. However, the Parties of the Agreement could not agree on the quintessence of the intended common market, given the importance of integration processes. While Russia wanted to establish an independent union within a strong (Eurasian) confederate union, Ukraine was pursuing a course in the European Single Market.

There was no way over the profound divergence of interests among these countries, which is the main reason why the objective of creating the 'common European and Eurasian markets' were contentious but (provisionally) mutually acceptable.

Russia needed the CIS to become a strong decision-making body, and it sought to (re)integrate the postSoviet zone both politically and economically. However, Russian efforts to transform the CIS, along the lines of the Soviet Union, into a single effective bloc, were not successful.

The original attempts to set up a "joint army," and to retain the same currency have collapsed, as the formation of their own military forces and the adoption of national currencies are perceived to be crucial in consolidating the newly (re)established statehood in all post-Soviet countries (including Russia).

Yet on 15 May 1992 the CST, which was joined by Azerbaijan, Belarus, Georgia at its entry into force (20 April 1994), was adopted in Armenia, Kazakhstan, Kyrgyzstan, Russia, Tajikistan, and Uzbekistan. 
But the effort to include all CIS countries in one joint defense bloc failed as it was vetoed by Moldova, Turkmenistan, and Ukraine. In addition to that, Turkmenistan (which called for absolute neutrality) and Ukraine (which led the way towards Euro-Atlantic integration) refused to ratify the 22 January CIS Charter.

In 1993 a multi-use regional organization was envisaged based on a close cooperation between its members, in both military and economic fields.

Global convergence attempts on a new framework for the international economy resulted in the introduction, on 24 September 1993, of the CIS Economic Union Treaty, aiming for a democratic creation of a free trade area (FTA), a customs union, a single business union, and then economic and monetary unions. Although on 15 April 1994 an FTA Agreement (as the first step towards the Economic Union) was signed, this document remained ineffective as Russia refused to ratify it. For Moscow, the FTA establishment with postSoviet countries made sense only as an inseparable part of the CIS Economic Union. Since it subsequently failed to persuade Ukraine to be a part of this Union (and thus to abandon its ambitions towards integration into the EU and NATO), Russia had little interest to open up its market and to supply its energy-carriers to Ukraine at its domestic prices.

By 1995, it was clear that the creation of a single "geopolitical space" encompassing the entire CIS was not possible soon due to fundamental disagreements between its Member States over the purpose of their organisation. One camp, led by Russia (and supported primarily by Belarus and Kazakhstan), envisaged the CIS as a vehicle for closer military-political and economic integration, while another camp, composed in particular of Azerbaijan, Georgia, Moldova and Ukraine, visualized the CIS as a transitional organisation intended to prepare the individual republics for complete independence.

While the first camp strove to create a system of collective security and an economic union, the second camp was interested in creating merely a free trade system and brushed away any plans to enter any militarypolitical alliances.

As a result, the CIS has become merely a loose intergovernmental organisation for broad regionalpolitical discussions and economic co-operation aiming at the creation of an FTA, while advanced integration processes started to be pursued within different camps and groupings. Among those groupings, two organisations are of particular interest: the CSTO and the EurAsEC, which in our opinion constitute de facto a single structure.

\section{Formation and Consolidating Factors of the Eurasian Alliance}

\section{Initial Phase}

With the ending of CIS integration processes in failure, efforts in the second half of the 1990s were made among those CIS countries which were willing to establish an effective collective security block and integrate their economies into an economic union. Belarus and Russia then entered into an Agreement on Customs Union on 6 January 1995 with a view to stronger political and economic ties. Kazakhstan joined this coalition on 20 January 1995 and Kyrgyzstan on 29 March 1996. This partnership represents the willingness of the countries' political leaders to enhance their influence amid a prolonged economic downturn. This community is named Customs Union.

Anyway, given four states' different economic policies and substantial discrepancies over trade policy with other countries, it was clear that the goals of the Customs Union were unrealistic in the short term. As a result, both leaders of the coalition saw that defensive obstacles against each other were the only possible response against their problems during the Russian financial crisis of August 1998.

The Eurasian alliance did not take measures to establish the CIS collective protection structure and solve various foreign problems in the post-Soviet zone due to the horrible economic condition (in particular, in Abkhazia, Nagorny Karabakh and South Ossetia). Those who took part in the CST, Azerbaijan, Georgia and Uzbekistan, agreed not to continue this initiative at its expiry in April 1999. The same month, these three 
States joined Ukraine and Moldova as an alternative to the emerging Eurasian alliance, forming an organization called GUUAM.

\section{Establishment}

The Eurasian Alliance's challenging time, however, did not force its leaders to leave it. On the contrary, they have all shown interest in strengthening their organisation, and even succeeded in attracting new members. On 26 February 1999, the framework treaty on Customs Union (SES) was signed by Belarus, Kazakhstan, Kyrgyzstan, and Russia, along with Tajikistan (the Five), with the intention of establishing a customs union and, after that, a SES.

Soon thereafter, on 2 April 1999, the Taliban powers in Afghanistan invaded the Tajikistan frontier in 2000, and all CST States Parties vowed to protect the nation of Tajikistan and to create a joint rapid response force to assist all endangered member countries, which would then be expanded by the Five and Armenia for a further five-year period.

The Treaty on the Eurasian Economic System was ratified by the Five on 10 October 2000. The formation of a single market explicitly demanded that the institutional structure of the recently established partnership be reinforced. Therefore, this Treaty, containing just 20 chapters, primarily sought to attach some new elements to the legal status and decision-making of the alliance in addition to previous agreements (particularly the Convention on Customs Union and the SES, 1999).

Meanwhile, the post-11 September 2001 US-led War on Terror has had significant consequences for national defense growth in Eurasia. The CST parties, with their support in the international anti-terrorist campaign, stepped up efforts to develop their group into a corner stone of the regional security system. The Five and Armenia then agreed to develop their relations on 7 October 2002 and set up an independent, inclusive association CSTO.

The establishment of EurAsEC and CSTO came during a favorable economic condition (increasing prices for oil and raw materials) in Eurasian countries (Russia and Kazakhstan), which enabled them to accumulate considerable financial reserves.

Moreover, they began, after the turn of the millennium, gradually to consider how sustainable and consistent economic growth outside natural resources could be achieved, whilst a further common denominator had been the intention to establish a common collective security system (especially to combat terrorism). Therefore, they have begun an institutionalizing cycle, generating impetus for greater integration.

Unlike the CIS, the EurAsEC and CSTO had clear legal capacity to fulfill their functioning and objectives (25). Thus, two regional organizations emerged in Eurasia at the beginning of the new century that were almost identical in membership and pursued the objective of concluding international treaties.

\section{Membership and Consolidating Factors}

Despite several setbacks in the 1990s, Russia continues to be one of the global powers and is keen to maintain and expand its economic and political influence. Moscow sees the formation of a single Eurasian coalition as a means of reinforcing its grip on post-Soviet countries and improving its bargaining role in foreign affairs. Russia is thus the main and guiding power behind both the CSTO (which consists of six nations Armenia, Belarus, Kazakhstan, Kyrgyzstan, Russia and Tajikistan) and EurAsEC (with the exception of Armenia). Russia tried to engage another country, Uzbekistan. The Kremlin (unlike the EU and the USA) declined to condemn Tashkent and gave it more comprehensive political and economic collaboration after the Andijan case in 2005 on a demographic basis, the largest nation in Central Asia. Consequently, by leaving the Eurasian coalition, Uzbekistan split from the GUUAM in January 2006 and was replaced by the CSTO in June 2006, all of which replaced the EurAsEC.

However, Uzbekistan has agreed in November 2008 and CSTO in June 2012 to suspend its membership of the EurAsEC, owing to increasing integration processes in Eurasia in the last few years and the steady change in Western ties. 
The idea of a strong Eurasian alliance is supported by all these countries (especially Belarus and Kazakhstan but also Kyrgyzstan, Tajikistan and Armenia). They share Russia's views on assessing geopolitical challenges (especially NATO expansion, the growth of Islamic fundamentalism, and China's rise) and concentrate on the restoration and preservation of conventional economic ties within the former Soviet Union. Moreover, Russia, Belarus and the bulk of Central Asian countries have identical centralized authoritarian (semi-) systems focused on controlled national elections, under which authority is centralized in the hands of the respective leaders.

The leaders of these countries consider the Eurasian alliance as a simple and effective mechanism to legitimize their regimes through political stability and sustained economic development. It should also be noted that the Eurasian Alliance's uniting factors consist in similar social and cultural traditions, as all these countries share a common historical background and a common Russian lingua franca.

Armenia is Russia's conventional partner. It is in a (now frozen) conflict over Nagorno-Karabakh with Azerbaijan and is keen to take part in the CSTO in a vital way. Armenia had been reluctant for a long time to join EurAsEC claiming it has no direct customs frontiers with other alliance members. Another explanation was that a large part of the polycentric Armenian bourgeoisie needed their nation to seek European integration. Yet Armenia agreed to ink an EU Partnership Agreement in September 2013 and chose to join the new Eurasian Economic Union.

Belarus (like Russia) is very susceptible to NATO expansion in recent decade and supports a 'multipolar world'. Belarus is also a part to Soviet heritage with a significant number of manufacturing industries, which rely heavily on raw materials and which demand Eurasian markets (various defense companies) from Russia (and other Eurasian countries). Consequently, Belarus initiated the most ambitious unification project in the postSoviet world to this day, with its official goal of establishing a joint military forces (that exists with both national armies of both countries) and a shared currency, the Belarusian-Russian quasi-federation union, named the Sojuznoe gosudarstvo, the "Unity state.» However, this initiative became almost frozen with the transition in Russian leadership by the turn of the millennium, with all unification proposals in the Eurasian alliance system being introduced.

The Central Asian countries Kazakhstan, Kyrgyzstan and Tajikistan are (like Uzbekistan) directly threatened by the expansion of Islamic fundamentalism (especially from Afghanistan), and therefore are interested in cooperating closely with Russia in combating a broad range of border security issues, including illegal migration, drug and weapons trafficking and terrorism. Along with anti-terrorism, major consolidating factors were also fears of civil resistance and internal revolutions as well as the US-led democracy enforcement campaigns in the mold of Afghanistan and Iraq.

In addition, these countries are interested in co-operating within the framework of the CSTO, as it provides the possibility to purchase Russian weapons and military equipment on favorable terms (in turn, Russia itself strongly encourages this reliance on its weapons since it promotes its military industries and consolidates the CSTO by harmonizing military equipment and tactics). Even if the countries in Central Asia were attempting to establish integration projects between themselves, through the development in 1994 of the Central Asian Economic Community that became the Central Asian Cooperation Organization (CACO) in 2002.

Such attempts have been ineffective, especially because the economies of Central Asia never formed a single autonomous structure. Kazakhstan has a 6,846-kilometer long border with Russia (the world's longest continuous border) and a significant share of the Russian-speaking population. As one of the world's major oil producers, however, it is anxious to diversify its economy and thus gain access to large markets. The countries with mainly agricultural economies are Kyrgyzstan and Tajikistan (as is Uzbekistan). They strive for freedom of travel, not just in terms of commodities but also primarily in terms of ample workers' capital, to promote unification in Eurasia.

\section{Major Areas of Co-operation within the Eurasian Alliance}

The Eurasian alliance has two main areas of cooperation fully in line with its two pillars: (1) establishing a system of collective security under the CSTO, and (2) creating a single economic area within the EurAsEC. 


\section{Eurasian Collective Security System}

The CSTO's quintessence is to construct and maintain an effective system of collective security (that is, a political arrangement by which states agree to take collective action against an outside party that acts as an aggressor). In other terms, the CSTO (and particularly its major force Russia) is not dedicated to the principle of multiple polarity, i.e. a fairly equitable division of control through a variety of world players, as compared to efforts to create hegemony over one (or the other) The CSTO seeks to maintain not only stability and protection in Eurasia but at establishing a 'joyous world order'.

With regard to the operation of a collective security system, CSTO members agreed to coordinate both their militiamen (through the establishment of regional armed groups), as well as their foreign and security (through consultations on all major international issues and security) policies. In return, all CSTO members undertook not to join or participate in military alliances to any other State party not to enter into international treaties inconsistent with the treaties adopted in the CSTO and not to allow armed forces and military establishments of third states to be stationed in their own countries.

But it is also clear that, for close cooperation in military and security issues, the CSTO Member States (except for Russia) have different interests. As a result, the CSTO consists virtually of three distinct collective security systems (Eastern Europe, Caucasian and Regional Asian) with a primarily interest in pursuing specific (mostly local) goals.

Most of them still share the fear that over the last decade, Georgia, Ukraine and Kyrgyzstan have been rocking through "color revolutions." It is very indicative that a joint CSTO peacekeeping force was established in October 2007, following a series of successful and tentative government overthrows in the CIS countries. In theory, this force can be deployed throughout the world under a mandate from the United Nations; but it is evident that this move was intended primarily to establish the monopoly on 'the maintenance' of the CSTO within and even in the entire CIS.

In addition, in February 2009 the Collective Rapid Reaction Force (CRRF) of up to 200000 soldiers was established, with the objective of repelling military assault, performing anti-terrorism operations, and even neutralizing the effects of natural disaster. In this respect, it should be noted that the Charter of the CSTO does not contain provisions on people's democratic will or on human rights protection. The quick reaction (or peacekeeping) CSTO forces are most likely to be used to guarantee stability in the CSTO member States' territories.

Regarding foreign and security policy coordination, CSTO is struggling to damage its members' positions on global and international trends and to cooperate closely with other States and intergovernmental organisations, especially issues related to the fight against international terror and extremism, arms and drug trafficking, cross-border illegal immigration and transnational organized crime. The CSTO has therefore been a productive relationship with the U.N. In order to develop a unified frontier control and migration policy, it works closely with EURAsEC on many matters such as harmonization and unification of national laws governing frontier and visa policy in the area of the common security as well as the economic area. The dynamic relations are also an essential component of the creation.

At the same time, despite repeated attempts the CSTO was not able to formalize relations with NATO and the OSCE, as those organisations have been reluctant so far to conclude any agreements with the CSTO, fearing that such a step would seal Russian dominance on the post-Soviet area.

Instead, those organisations have focused on direct co-operation with the CSTO's individual members, not least of all because many of those members consider collaboration with NATO and OSCE as an integral component of their foreign and security policy. Even though during the recent crisis in Ukraine the CSTO Secretariat announced that it would halt its contacts with NATO and instead strengthen co-operation with the SCO, it is doubtful that all CSTO members will unequivocally follow Russia in freezing relations with the West.

Unlike the Warsaw Treaty Organisation, the CSTO is not fastened together by ideological bonds and its members are free to withdraw from the organisation and to pursue their own foreign and security policies. This flexibility is certainly another reason (along with the pro-claimed goals of combating terrorism and drug 
trafficking, the threat of Islamic fundamentalism, fear of "color revolutions", perceived NATO interference and belief in Russia as an effective counterbalance) why the CSTO will be of value for its Member States as an organisation capable of addressing both external and internal threats and guaranteeing their sovereignty. In addition, CSTO has on several occasions over recent years reiterating its pledge to improve its military capability before the withdrawal from Afghanistan of the NATO-led security mission in 2014, as there is important explanation why Islamic extremists fear that their presence in the area might be increased.

\section{Eurasian Economic Space}

The EurAsEC was designed with the following two main objectives: 1) to create a customs union between its Member States and 2) to establish a SES based on the customs union. As it is obvious, a customs union was never considered a final objective but a prerequisite for a SES. International experience actually shows that the customs union's operation is not sufficient to fully ensure the free flow of goods and all its concurrent products and logically leads to the elimination of restraints on the movement within, and hence to the creation of a common market, of the so-called production factors (labor, services and capital). In achieving these goals, the Eurasian states pledged to build their relations on principles of mutual advantage, good will, equality, transparency and accountability.

As in international practice, EurAsEC members decided to fully liberalize trade (through the establishment of an effective FTA) and subsequently to establish a common set of tariffs barriers against the rest of the world by pursuing the development of the customs union. However, there was no reason for hope in the initial production of EurAsEC. Although the members of the EurAsEC could agree to remove most tariffs and quotas in mutual trade in goods (thus establishing an effective FTA), they could not progress towards harmonizing their Foreign Commerce Policy with third countries.

The main reason for this inability was that the consolidation of their national state ships and the resolution of many economic transition problems were of concern to every Eurasian country. They had chosen various political and economic paths in the establishment of their new states and as a result, their business regimes were incompatible.

Note also that the collapse of the USSR has led to an unprecedented economic recession and a significant decline in trade between the post-Soviet republics. Consequently, the CIS countries share of the Russian foreign trade, and Russia also loses its leading position in trade with most of the CIS countries.

Consider that the Eurasian integration is not a business project but an economic one, and the EurAsEC constitutes an economic complement to the CSTO. The Eurasian integration is an economic complement.

Furthermore, the Eurasian Alliance is defined by Russian domination, creating considerable difficulties in achieving a mutually reasonable equilibrium among Eurasian countries, ensuring that successful supranational structures are established while simultaneously ensuring that EurAsEC leaders have a supreme interest. In addition, Russia (like all other Eurasian countries), the leading Member of the Alliance, was subject to significant economic challenges and thus unwilling to move integration processes further (and thus embrace very costly obligations).

The situation, nonetheless, started to change by 2003 with Russia (and Kazakhstan) embarking on the course of achieving a sustained increase in national income outside the extractive sector and taking advantage of the rising oil and other commodities (as well as market-economy-measurement reforms and inflow of foreign investment). The Kremlin then began to pursue Ukraine's entrance into EurAsEC, a move which would not only further extend the Eurasian alliance but also bring about a more appropriate power structure (thus raising the likelihood of forming supranational bodies).

As a result, on 19 September 2003 Belarus, Kazakhstan, Russia and Ukraine concluded the SES Agreement, which foresees, on the one hand, that each State party would select a desired integration level (from FTAs to a common market) in its own right but on the other hand clearly aims to create the SES as its ultimate objective. The Agreement presented Ukraine with substantial changes representing a major change in Russia's integration 
policy, which was now capable and ready to make financial obligations to enable the other CIS countries to push towards their unification initiative and thus to expand the borders of the Eurasian market. However, the SES' incompatibility with the country's strategic goal of integrating itself into Euro-Atlantic structures, proWestern movements in Ukraine have declared after the Orange Revolution.

Although the integration project was frozen with Ukraine, Belarus, Kazakhstan and Russia decided to proceed in the EurAsEC format. But it was evident that less developed EurAsEC members were not yet ready for deep processes of integration (mostly on economic grounds). Although in June 2005 Kazakhstan and Russia set up the Eurasian Development Bank to fund shared projects with neighboring countries, this move obviously was not enough, to remove the huge heterogeneity among Eurasian countries.

It was decided by EurAsEC members in August 2006 and formalized on 6 October 2007, which led to the idea that three advanced members, Belarus, Kazakhstan and Russia, would create a trilateral solution. The Solution was founded in August 2006.

TOMS Union68, whilst the other leaders are taking measures towards liberalizing their trading laws and / or increasing their economic performance, and then entering the Customs Union, as far as feasible. Moreover, Belarus, Kazakhstan and Russia are committed to establishing a supranational body (the Commission) and enabling the Customs Union to become effective by 2010, the first time the customs union is finished on time. Throughout the EurAsEC, the so-called Tamozennyi Soyuz, the Customs Union of Belarus, Kazakhstan and Russia have therefore effectively formed a sub-organization.

On 27 November 2009, the Three signed a package of documents (the most important among them - the common Customs Code), which came into force on 1 January 2010 and unified the rules for customs controls applied to goods originating in third countries (i. e. establishing common external tariffs).

The next step was taken on 1 July 2010, when customs controls at the internal customs borders were eliminated and the process of creating the Customs Union was effectively completed.

The formation of a customs union was regarded as the first step towards the establishment of a SES right from the start of integration processes in Eurasia. In fact, already on 19 December 2009 (on the eve of launching the Customs Union) the Three adopted an Action Plan for 2010- 2011 envisioning the creation of a SES within the next two years. Consequently, on 1 January 2012 the establishment of the Edinoe Ekonomicheskoye Prostranstvo (SES) was officially proclaimed.

The Presidents of Belarus, Kazakhstan and Russia decided on 19 December 2011 to rearrange EurAsEC to the Eurasian Economic Union (USA) by 2015 and encouraged the other members of EurAsEC (Kyrgyzstan and Tajikistan) and EurAsEC observers (Armenia, Moldova and Ukraine) to begin the process of becoming a new EU part. Russia has tried to get Ukraine involved in the USA. The Kremlin intensified its efforts to persuade the Ukrainian leadership to embark upon integration projects led by Moscow, after the defeat of the pro-western candidates in 2010.

However, Kiev finally turned west after the Maidan Revolution (2013-2014) and its subsequent confrontation with Russia. Moldova took the lead and openly declared its aspiration to the Europe. The third party signed on 29 May 2014 the Treaty on Eurasian Economic Union that will enter into force on 1 January 2015 expressed its intention to join Kyrgyzstan and Tajikistan.

\section{Institutional Framework of the Eurasian Alliance}

Both CSTO and EurAsEC/EU have the institutional structure of legislative, parliamentary, representative and administrative bodies (in addition, EurAsEC has its own specialist judicial body). While CSTO structures are established and completely structured in compliance with concepts of intergovernmental collaboration, there is also an emerging and well-defined institutional system for EurAsEC / EU.

\section{Supreme Bodies}

The institutional framework of both CSTO and EurAsEC is entirely dominated by their respective supreme bodies (the Collective Security Council at CSTO, the Interstate Council of EurAsEC and the Supreme Eurasian 
Economic Council (SEEC) at the EE, reflective of the constitutional structures of the Member States (all republics with strong Presidents).

The SEEC and ICC may also meet on government level (at least twice a year); they shall decide, in accordance with the direction provided by the Heads of State, important (mostly economic) issues by consensus. The SEEC is apparently to replace the IC after the full implementation of the EEU (which replaces the EurAsEC).

\section{Executive Bodies}

Because of the CSTO problems, the administrative bodies include: the Foreign Ministers' Council, the Ministers' Council, the Group of National Security Council Secretaries and the Permanent Council (a permanent group of Member States' representatives). Their actions are supported by various working bodies (such as the Joint Staff of the CSTO; the Committee on Military and Economic Cooperation; the Council on the fight against Illegal Migration; and the Council on Emergency Related Migration) and the CSC decisions are taken through consensus to implement the CSC decisions.

The EurAsEC executive body is the Integration Committee, which consists of Deputy Heads of State and meets every three months. In its activities, 20 auxiliary bodies (diversely composed of ministers and heads of different agencies) and the Committee of Permanent Representatives are assisted (a standing body composed of member states' they are responsible for preparing proposals for the $\mathrm{IC}$ and for monitor the IC decisions implementation. The Integration Committee and the Permanent Representative Commission can both decide on two thirds by 'weighted vote'. However, both institutions' decisions simply have a recommended nature.

With a binding majority of two thirds (by which Russia had 50 votes while Belarus and Kazakhstan 21.5 votes respectively), the Three created a Commission on 6 October 2007 under the Customs Union of Belarus, Kazakhstan and Russia. Although if one of the parties were not able to acknowledge the Commission's ruling, it may refer the matter to the supreme body (and thus demand that decisions on this issue be made by consent). In addition, a request to review any decisions of the Commission could be made by any party to the superior body.

Nonetheless, the Three created a new Committee, the Eurasian Economic Commission on 18 November 2011, which could take binding and directly applicable decisions and consists by two houses: the Council and the Board. Nine members are members of the Board (The SEEC can take decisions by a two-thirds majority (three from each Member State) appointed for a four-year term by the SEEC (meeting at Head of State level).

The Board is responsible for making proposals to the Council for the purpose of integration and the implementation of the SEEC and Council's decisions, and the monitoring of the agreements implementation underlying the Customs Union and the SE. Then, each of the representatives of the Council can disagree with the Board's decision and submit it to the SEEC (and therefore send it to a consensus for the adoption of that decision). The Council alone can initiate the proceedings before the EurAsEC Court against Member States which do not comply with their obligations under the agreements that underlie the Customs Union and the SES.

Consequently, the Eurasian Economic Commission is currently not a functional equal to the EU Commission. The Council may submit proposals (in particular, draft international agreements). But it is obvious that the Eurasian countries have tried to establish an agency that would effectively guard the treaties and agendas of the USA. The nature of a SES involves the transformation into a fully supranational entity of the Eurasian Economic Commission and this development would certainly decide if SES is viable and if the EU will be transformed into a true organisation.

\section{Administrative Bodies}

Both EurAsEC and CSTO are permanently secretarial. They are headed by Secretaries-General who are named for a three-year period by the respective supreme bodies (for EurAsEC it shall be achieved on a recommendation from the Committee for Integration). Both the Secretaries General and the staff of the Secretariats (as the plenipotentiary of state party representatives both organisations and employees of the working bodies) are generally accepted in international practice to have broad diplomatic immunities. 


\section{Dispute-Settlement Bodies}

Unlike the CSTO, where the CSC is the only institution that can deal with disputes between Member States (if those disputes could not be settled through negotiation) a Court composed by two judges from each Member State appointed to the Parliamentary Assembly on a request from the Interstate Council for a mandate shall be the institutional framework of EurAsEC. Main Court's tasks: (1) to ensure unitary adherence of the Member States to the whole EurAsEC treaty and decision-making of the EurAsEC bodies; and (2) to resolve disagreements on matters related to the enforcement of EurAsEC treaties and decisions of a 'material essence' between Member States.

On 27 April 2003, the Court introduced its first Statute. The Court has had automatic authority in respect of cases made by State Parties to the Trial, in accordance with the CIS (the CIS Economic Court), but unlike the former Trial (the rulings of which are of only a Recommendable Character) the Court's judgments will be enforced, by its national constitutional arrangements, by the Member States Parties for three months.

Nevertheless, the EurAsEC representatives did not decide on the entry into force of the Statute; the EurAsEC Court duties were thereby automatically transferred to the CIS Economic Court.

With the aid of the unification processes in Eurasia, the situation started to improve. The EurAsEC representatives adopted a new, significantly modified Statute on 5 July 2010.

Owed the Court to assess (within the Customs union) not only the acts of States parties but also the institutions of EurAsEC and, more specifically, the economic agencies of the Member States of the Customs Union. The EurAsEC Court began working on 1 January 2012 and released its first decision on 12 September 2012.

\section{Representative Bodies}

Both the CSTO and EurAsEC have their parliamentary assemblies, which perform representative functions and which, through drafting Framework Legislation and Model Legislation, work on harmonization of national legislation in the Member States.

The parliamentary assembly of the CSTO comprises parliamentary delegations of Member States, like the analogous body that is existing within the CIS framework. The parliamentary assembly of EurAsEC shall be composed of representatives from the national parliaments of the Member States (the 28 delegates of Russia, 14 from Belarus, Kazakhstan and Uzbekistan, and 7 from Tajikistan). Each delegation shall vote on the decisionmaking process and all decisions shall be taken through agreement. Every delegation shall be composed of a representative delegation. Two-three plurality decisions are accepted by the Congress. However, the Bureau, which comprises delegations of the Member States and governs by agreement, formulates the agenda.

However, with the formation of the Eurasian Economic Commission and the EurAsEC Trial, Kazakhstan and Belarus are currently opposed to the notion that a reform in EurAsEC Parliamentary Assembly would weaken their national sovereignty and maintain that advanced integration would weaken them.

\section{Problems and Perspectives of Integration Processes in Eurasia}

The international community is currently observing Eurasia's development as one of the new geopolitical centers in the world. This procedure comes from the political as well as economic factors including the desire for regional peace and security to be stabilized and an economic structure which would strengthen its power and influence on the international stage, especially in a number of post-Soviet countries. The method of creating a united Eurasia therefore takes place in the context of two separate but strongly linked coalitions, with a virtually similar membership: the CSTO and EurAsEC (now the USA).

The CSTO aims to create an efficient system of collective security that will entail a close and comprehensive alliance that will coordinate external and defense policy and will harmonize their efforts to combat international terrorism, extremism, or organized transnational crime, illegal migration and other security threats to its Member States. The CSTO, however, today mainly has different interests in closely cooperating on military and security issues in its Member States (except Russia). The CSTO comprises of three very distinct mutual defense 
subsystems (Belarus - Russia, Armenia - Russia, and Central Asia - Russia). In this respect it is obvious, that the only effective method of CSTO consolidation is by uniting the national economies of Eurasian countries into a strong economic alliance. If we look at the European expertise, where the integration processes were driven by precisely the economic component, we can assume that the creation of the united Eurasia will depend substantially on progress towards an EEU.

The economic pillar of the Eurasian Alliance is endowed with certain elements of supranationalism, as opposed to the CSTO (the military-political pillar of the Eurasian Alliance), which bases itself entirely on the principle of intergovernmental cooperation. The creation of the Eurasian Economic Commission and the EurAsEC Court are particularly noteworthy in this respect. The formation of such bodies shows that the Eurasian states may theoretically diverge from their strict adherence to the concept of sovereign independence and turn into a supranational body (which, through progress towards the establishment of the economic union, is logically needed).

Examining the institutions of the USA and the progress of its stages, a striking similarity with the European integration process that led to the establishment of the European Union of the present day can easily be noticed. However, the legal nature of both integration groups is quite different: whereas the EU is in principle (mostly) a decentralized association for parliamentary states, the Eurasian Alliance is a high-centralization Presidential Republic union. The Eurasian Alliance. Therefore, the competition of two opposite models of regional integration characterizes the current situation (particular because of the recent proliferation of integration processes in Eurasia).

The future of the Eurasian integration process remains uncertain. Obviously, the creation of an efficient supranational body includes such advanced institutions as the SES and the Economic Union. At the same time, only under the separation principle of powers between the organization and its Member States, supranational organisations can exist. This division calls for an interaction with democracy and rule of law, that is, with fundamental ideas which will ensure that inclusion is seen as a way of strengthening national sovereignty by growing peace and protection and ensuring stronger economic development rather than a danger to such sovereignty. This is a significant obstacle for the presidential republishing Eurasian countries, as the actual political decision taking of the Eurasian countries (in place of institutional adherence to democratic values) is feasible only with considerable difficulties inside EU (parliamentary).

In that regard it is necessary to remember that conditions that lead to the Eurasian Alliance's unification include not only a willingness to foster political stability and to stimulate economic development, but also the apprehension of 'color revolutions' in their countries of the respective political elites. Consequently, in Eurasia, global integration processes rely on a relatively small number of nation leaders mainly concerned with preserving and improving their own political control. The absence of democratic liberalization in Eurasian countries therefore would undoubtedly hamper national integration procedures, which would similar the Eurasian alliance to a 'piece big' focused solely on certain policymakers' person will.

Nevertheless, as Eurasian States increase their political will to begin their processes of incorporation into the full EEU nature (thus towards establishing successful supranational institutions), as they move towards the creation of democracies, the further their working supranational bodies would entail the adherence of Eurasian countries to the Democrat. The future Eurasian Union can therefore be founded on the same values and principles that the EU has, and that could form a solid foundation for collaboration between the two groups to build an area of freedom, security and prosperity between the Atlantic and the Pacific for all the people who live there.

\section{References / Литература}

1. Adam Weinstein, "Russian Phoenix: The Collective Security Treaty Organization", 8 (1) The Whitehead Journal of Diplomacy and International Relations (2007), 167-180.

2. Alena Douhan, "Commonwealth of Independent States: Is There Any Chance to Establish an Effective System of Collective Security in the Region?", 15 Max Planck Yearbook of United Nations Law (2011), 281-327. 
3. Alex Danilovich, Russian-Belarusian Integration: Playing Games Behind the Kremlin Walls (Aldershot, Burlington, Ashgate, 2006).

4. Alyaksandr Tsikhamiraw, "Russia in the Foreign Policy of Belarus", in Valer Bulhakaw (ed.), Belarus-Russia Integration (Minsk 2003).

5. Angelika Nussberger, "Supranationales Recht jenseits des Ural", 56 (1) Osteuropa-Recht (2010), 113-121.

6. Christoph Schewe \& Azar Aliyev, "The Customs Union and the Common Economic Space of the Eurasian Economic Community: Eurasian counterpart to the EU or Russian domination?", 54 German Yearbook of International Law (2011), 565-606.

7. Christoph Schewe, "Das Recht der Zollunion der Eurasischen Wirtschaftsgemeinschaft: postsowjetische Integration nach dem Vorbild der EU?" 24 (14) Europäische Zeitschrift für Wirtschaftsrecht (2013), 535539.

8. Dmitri Trenin, "NATO and Russia: Sobering Thoughts and Practical Suggestions", NATO Review (Summer 2007), available at <http://www.nato.int/docu/review/2007/Partnerships_Old_New/NATO_Russia_ practical/EN/in dex. htm>.

9. Frank Haight, "Customs Unions and Free-Trade Areas under GATT: A Reappraisal", 6 (4) Journal of World Trade Law (1972), 391-404.

10. Gennady Danilenko, "The Economic Court of the Commonwealth of Independent States", 31 (4) New York University Journal of International Law and Politics (1999), 893-918.

11. Guillaume van der Loo and Peter van Elsuwege, "Competing Paths of Regional Economic Integration in the Post-Soviet Space: Legal and Political Dilemmas for Ukraine", 37 (4) Review of Central and East European Law (2012), 412-447.

12. Joachim Lippot, "The Commonwealth of Independent States as an Economic and Legal Community", 39 German Yearbook of International Law (1996), 334-360.

13. Luk van Langenhove, Building Regions: the Regionalization of the World Order (Ashgate Publishing, Farnham, Burlington, 2011).

14. Marina Trunk-Fedorova, "Der Gerichtshof der Eurasischen Wirtschaftsgemeinschaft", 59 (4) OsteuropaRecht (2013), 413-422.

15. Marise Cremona, "The European Neighbourhood Policy: More than a Partnership?", in Marise Cremona (ed.), Developments in EU External Relations Law 244 (Oxford University Press, Oxford, 2008), 244299.

16. Nursultan Nazarbayev, Evraziiskii Soiuz Idei, Praktika, Perspektivy. 1994-1997 (FSRSPN, Moscow, 1997).

17. Olexandr Pavliuk, "GUUAM. The maturing of a Political Grouping into Economic Cooperation", in Renata Dwan \& Olexandr Pavliuk (eds.), Building Security in the New States of Eurasia: Subregional Cooperation in the Former Soviet Space (Sharpe, Armonk, NY, 2000).

18. Pradeep Mitra \& Marcelo Selowsky, Transition. The First Ten Years: Analysis and Lessons for Eastern Europe and the Former Soviet Union (World Bank, Washington, DC, 2002).

19. Richard Pomfret, The Economies of Central Asia (Princeton University Press, Princeton, 1995).

20. Richard Sakwa \& Mark Webber, "The Commonwealth of Independent States 1991-1998: Stagnation and Survival”, 51 (3) Europe-Asia Studies (1999), 379-415.

21. Rilka Dragneva \& Joop de Kort, "The Legal Regime For Free Trade in the Commonwealth of Independent States", 56 (2) The International and Comparative Law Quarterly (2007), 233-266.

22. Rilka Dragneva, "Is "Soft" Beautiful? Another Perspective on Law, Institutions, and Integration in the CIS", 29 (3) Review of Central and East European Law (2007), 279-324.

23. Roger McDermott, "CSTO Proposes Cooperation with NATO on Afghanistan", Eurasia Daily Monitor (10 April 2012), available at <http://www.jamestown.org/single/?no_cache=1\&tx_ttnews[tt_news]=39246>.

24. Sergei Naryshkin and Taliya Khabrieva, "K novomy parlamentskomu izmereniyu", (8) Zhurnal Rossiyskogo Prava (2012), 5-15.

25. Sergei Voitovich, "The Commonwealth of Independent States: An Emerging Institutional Model", 4 (3) European Journal of International Law (1993), 403-429. 
26. Sherzod Shadikhodjaev, "Trade Integration in the CIS Region: A Thorny Path Towards a Customs Union", 12 (3) Journal of International Economic Law (2009), 555-578.

27. Theodor Schweisfurth, "Vom Einheitsstaat (UdSSR) zum Staatenbund (GUS): Juristische Stationen eines Staatszerfalls und einer Staatenbundentstehung", 52 (3/4) Heidelberg Journal of International Law (1992), 541-702.

28. Valentin Fissenko \& Igor Fissenko, "The Charter of Cooperation", 4 Finnish Yearbook of International Law (1993), 229-280.

29. Vratislav Pechota, "The Commonwealth of Independent States: A Legal Profile", 2 (4/5) The Parker School Journal of East European law (1995), 583-638.

30. Zbigniew Brzezinski and Paige Sullivan, Russia and the Commonwealth of Independent States. Documents, Data, and Analysis (Sharpe, Armonk, NY, 1997).

31. Zhenis Kembayev, "Basic Features of the Legal System", in Zhenis Kembayev (ed.), Introduction to the Law of Kazakhstan (Kluwer Law International, Alphen aan den Rijn) (2012), 23-35.

32. Zhenis Kembayev, "Legal Aspects of the Regional Integration in Central Asia", 66 Heidelberg Journal of International Law (2006), 967-983.

33. Zhenis Kembayev, "Problemy i Perspektivy Chlenstva Respubliki Kazakhstan v Shankhaiskoy Organizatsii Sotrudnichestva", (11) Yurist (2012), 42-52.

34. Zhenis Kembayev, "The (In)Compatibility between Regional Integration Processes in the Post-Soviet Area and within the European Neighborhood Policy", 59 (4) Osteuropa-Recht (2013), 369-377.

35. Zhenis Kembayev, Legal Aspects of the Regional Integration Processes in the Post-Soviet Area (Springer Verlag, Berlin, Heidelberg, 2009).

\section{About the authors:}

Khodor Shatila, MBA, Sagesse University (Lebanon, Beirut); shatilakhodor@gmail.com

Marina Alozian, MBA, Sagesse University (Lebanon, Beirut); maralozian@gmail.com

\section{6 авторах:}

Шатила Ходор, магистр делового администрирования (MBA), Sagesse University (Ливан, Бейрут); shatilakhodor@gmail.com

Алозян Марина, магистр делового администрирования (MBA), Sagesse University (Ливан, Бейрут); maralozian@gmail.com 